\title{
Research Article: Land resources inventory of Jantapur-1 micro watershed Lingasugur taluk, Raichur district
}

\author{
B. KUMAR NAIK, S.N. BHAT, S.R. BALANAGOUDAR, N.L. RAJESH AND \\ S.R. ANAND
}

Article Chronicle:

SUMMARY : Fourteen representative mapping units representing upland, midland, mid upland, lowland and near lowland in Jantapur-1 microwatershed of Lingasugur taluk, Raichur district in Karnataka were characterized and assessed for their nutrients content. The soils were shallow in upper slope and deeper in the lower slopes. Colour of the soil is reddish brown to very grayish brown, well, moderately to excessive drained, neutral to strong alkaline in reaction, low to medium in organic carbon and medium to high in cation exchange capacity with wide textural variations. Soils were low in available nitrogen, low to high in available phosphorus, potassium and sulphur. Whereas, copper, iron, manganese were sufficient but soils were deficient in zinc.

How to cite this article : Naik, B. Kumar, Bhat, S.N., Balanagoudar, S.R., Rajesh, N.L. and Anand, S.R. (2017). Land resources inventory of Jantapur-1 micro watershed Lingasugur taluk, Raichur district. Agric. Update, 12(TECHSEAR-5) : 1243-1250; DOI: 10.15740/HAS/AU/12.TECHSEAR(5)2017/1243-1250.

KEY WoRds:

Soil resources, Soil

survey, Soil

characterization

Author for correspondence :

\section{B. KUMARNAIK}

Department of Soil

Science and Agricultural

Chemistry, University of

Agricultural Sciences,

RAICHUR (KARNATAKA)

INDIA

Email : kumarbankar99

@ gmail.com

See end of the article for

authors' affiliations 